\title{
Challenges to Sustainability: Applying the Problem Tree Analysis Methodology to the ADP System in Nigeria
}

\author{
A. A. Ammani, S. J. Auta and J. A. Aliyu \\ National Agricultural Extension and Research Liaison Services \\ Ahmadu Bello University, Zaria \\ Email: aaammani@yahoo.co.uk ; Tel: +2348039606608
}

\begin{abstract}
The paper attempts an analysis of the problems (their causes and effects) militating against the sustainability, and by implication, the effective performance of the ADP system in Nigeria. A problem tree was constructed based on problems identified by recent reports of the Agricultural Performance Survey and the National Agricultural Extension Review and Planning Meetings, activities conducted by NAERLS in collaboration with other NARIs and Federal Agencies. The focal problem is inadequate funding. The developed problem tree was then transposed, thus transforming the root causes and consequences identified into root solutions. From the root solutions, the following available practical solutions were advanced: improving funding for the ADPs through deduction of state and federal governments counter-part funds for the $A D P s$ from source i.e. the federation account and formation of an Agricultural Development Tax Fund (ADTF) fashioned not in line with the Education Tax Fund (ETF) to provide additional and sustainable source of funds for agricultural development in Nigeria.
\end{abstract}

Keywords: Problem analysis, Funding, Sustainability, ADP System, Nigeria.

\section{INTRODUCTION}

The integrated Agricultural Development Projects, ADPs, were conceived in the early 1970s to attain 2 objectives: (a) increase food production and (b) raise the income level of small scale farmers in the rural areas through the provision of improved seeds, fertilizer, pesticides, credit facilities and infra-structure (Garba, 2000; Akpobo, 2007). The ADPs have evolved to be "permanent" institutions for rural infrastructural development and agricultural services (World Bank, 2001).

According to the World Bank (2001), "the ADPs were designed in response to a fall in agricultural productivity, and hence a concern to sustain domestic food supplies, as labor had moved out of agriculture into more remunerative activities that were benefitting from the oil boom. Conversely, domestic recycling of oil income provided the opportunity for the government, with Bank support, to develop the ADPs. The projects provided agricultural investment and services, rural roads, 
and village water supplies. The government's adoption of the ADP concept put the smallholder sector at the center of the agricultural development strategy, and marked a clear shift away from capital-intensive investment projects for selected areas of high agricultural potential."

The first generation ADPs started as enclave projects which covered few areas in three states: Funtua ADP (1975) in old Kaduna state, Gusau ADP (1975) in old Sokoto state and Gombe ADP in old Bauchi state. The success recorded by the enclave ADPs led the Federal Government to establish 6 more enclaves at Ayangba, Lafia, Bida, Ilorin, Ekiti-Akoko and Oyo North between 1979 and 1982 (Oladele, 2004; Akpoko, 2007). Today, ADPs have spread to all 36 states and the FCT. Zamfara state even has a parallel ADP called the Zamfara State Comprehensive Revolutionary Agricultural Programme, ZACAREP.

The ADPs are the main extension delivery organ of the extension delivery system in Nigeria. According to Ekpere (1990), restructuring a new role for agricultural extension within the ADPs derived from the argument that the previous concept and scope of extension in the Extension Services Division of Ministries of Agriculture was too broad, with the result that it could only provide limited service to the majority of farmers in their basic farming enterprises. Thus, within the framework of an ADP, the extension component is conceptualized as the medium through which improved technologies are channeled to farmers in the project area.

At inception, the ADPs were jointly funded by the Federal Government, State Governments and the World Bank up to 1995 when the World Bank's support ceased (Garba, 2000; Oladele, 2004). Fifteen years after the withdrawal of World Bank's support to the ADP system in Nigeria: what are the problems militating against the ADP system in Nigeria? Of the problems identified, which problem could be considered as a key problem of the system which if properly tackled will make the ADP system more effective as the main extension delivery organ of the agricultural extension delivery system in Nigeria? What are the practical solutions to the focal problem?

The purpose of this paper is to apply the Problem Tree technique to analyze the problems confronting the ADP system in Nigeria, with a view to understanding the challenges to sustainability of the system, leading to possible solutions that will ultimately make the ADPs vibrant and effective again.

\section{METHODOLOGY}

\section{Methodological Framework of the Problem Tree Analysis}

Problem tree analysis technique is employed in different forms of project planning and is a popular tool among development agencies. This subsection is based on Guijt and Moiseev (2001), UNESCAP (2003), AusGuideline (2005), DfID (2005) and Holtland (2005). Problems and their inter-relationships can be identified and visualized using the problem tree. The problem tree is a diagram showing the cause - effect relationships between problem conditions in a defined context. It includes all problems known by the participants and structures them in such a way that the more complex problems are broken down into simpler problems. Problem 
tree analysis helps to find solutions by mapping out the anatomy of cause and effect around an issue in a similar way to a Mind map, but with more structure. Problem tree analysis is best carried out in a focus group of about six to twentyfive carefully selected people using flip chart paper or an overhead transparency. It is important that factors can be added as the conversation progresses. The heart of the exercise is the discussion; debate and dialogue that is generated as factors are arranged and re-arranged, often forming sub-dividing roots and branches.

A good problem analysis consists of a number of steps. At least five steps can be distinguished:

1. Identify major existing problems, based upon available information.

2. Select one main problem for the analysis.

3. Identify important and direct causes of the focal problem and construct a tree showing these relationships.

4. Identify important and direct effects of the focal problem and construct a tree showing these relationships.

5. Review the entire problem tree, verify its validity and completeness, and make necessary adjustments. 


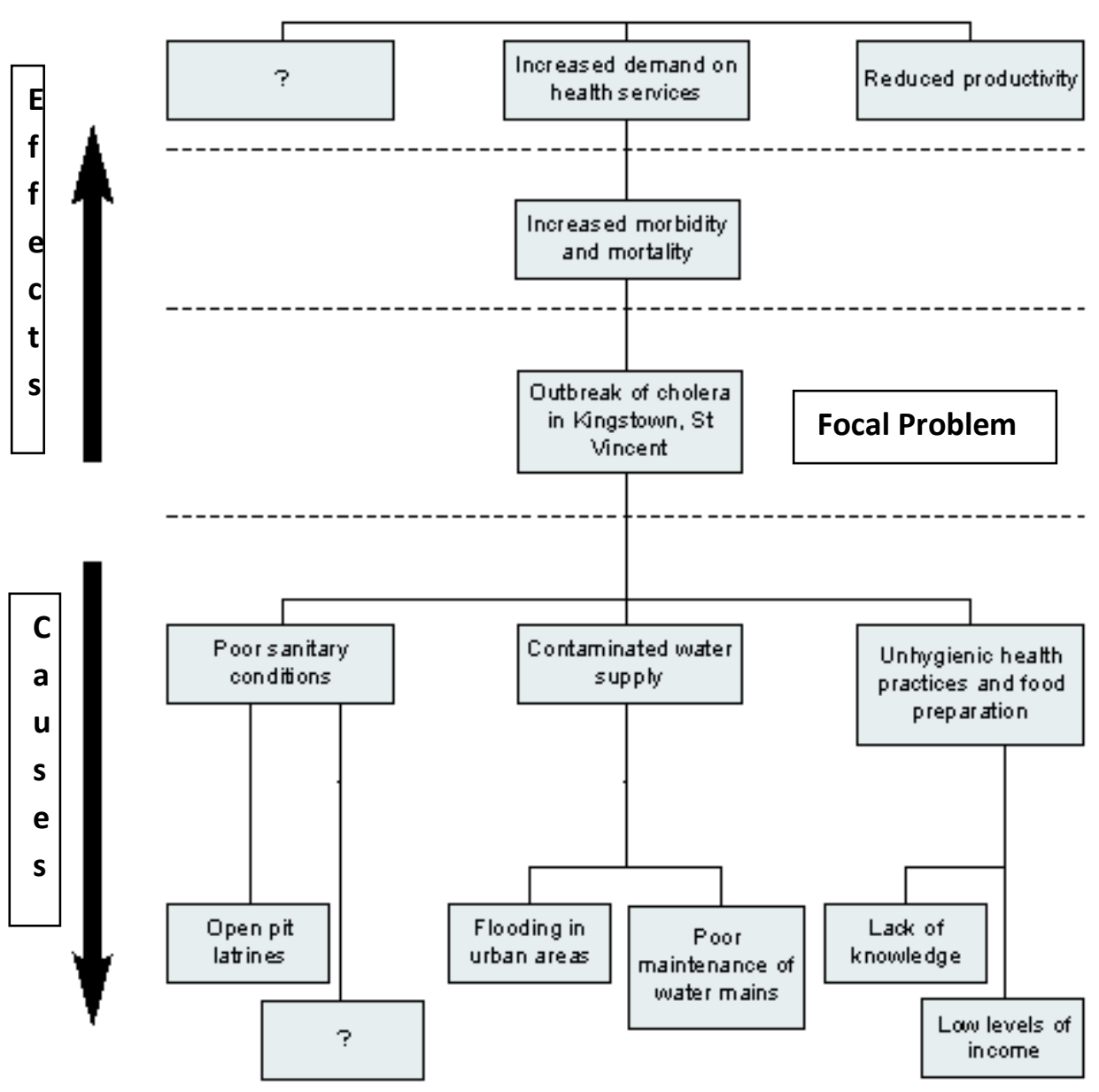

Fig. 1: Sample of a Problem Tree (DfID, 2005)

The Problem tree can be converted into an objectives tree by rephrasing each of the problems into positive desirable outcomes - as if the problem had already been treated. In this way, root causes and consequences are turned into root solutions, and key project or influencing entry points are quickly established. The objective tree can form the basis for further decision -making on alternative interventions (projects) that would aim to influence a given situation.

Procedure for constructing an Objective Tree is as follows:

1. Reformulate the problems as objectives;

2. Check the logic and plausibility of the means-to-ends relationship;

3. Adjust the structure wherever necessary and revise statements;

4. Delete objectives that are not desirable;

5. Check whether rewording will lead to meaningless or ethically questionable statements; in that case, reformulate the objective or indicate that this problem cannot be solved in the given context; and 
6. Add new objectives if they appear to be relevant and necessary in order to achieve the stated objective at the next higher level.

\section{METHODOLOGY}

This paper applied the Problem Tree technique to analyze the problems of the ADP system in Nigeria. Recent National reports of the Annual Performance Survey of Agricultural Production in Nigeria (NAERLS,2008a) and the National Agricultural Extension Review and Planning Meeting (NAERLS,2008b) were reviewed. The existing problems militating against the ADP system as identified in the reports were noted. From the identified problems, a focal problem, the most important problem in the opinion of this paper, was identified. A problem tree was then constructed based on the focal problem, this helped in identifying the direct causes and effects of the focal problem (Figure 1). The developed problem tree was then transposed to give the objective tree (Figure 2). The objective tree obtained provided the root solutions. From the root solutions available practical solutions were advanced.

\section{Results}

As earlier mentioned, the problem analysis process, including the identification of the focal problem, is carried out in a participatory manner. Thus, this paper applied the Problem Tree technique to analyze the problems of the ADP system in Nigeria in the following five steps:

Step 1: Identify major existing problems, based upon available information.

The major existing problems militating against the ADP system in Nigeria, as identified by the reports (NAERLS, 2008a; NAERLS, 2008b) are: lack of service vehicle/mobility, lack of qualified extension staff, lack of incentives/motivation for extension staff, lack of working materials, lack of in-service training, poor funding, inadequate/late delivery of farm inputs to farmers and poor supervision of extension workers.

Step 2: Select one main problem for the analysis.

From the identified problems, this paper considered poor funding as the main problem for analysis. This is because most of the identified problems can be traced to poor funding. Thus, poor funding was taken as the focal problem of the ADP system in Nigeria.

\section{The Focal Problem, Inadequate Funding: Trends and Causes}

Poor funding was taken as the focal problem of the ADP system in Nigeria. From the inception of the ADP system in Nigeria, it has been jointly funded by the Federal Government, the State Governments and the World Bank. The initial funding ratio, according to Madukwe et al (2002) was World Bank (66\%), Federal Government (20\%) and State Governments (14\%). The World Bank's support, which was in form of an external credit, ceased in 1995. Table 1 revealed that the funding of the ADPs was shared almost equally between the Federal Government, States Government and the World Bank from 1981-1985. Between 1986-1993 the 
share of the Federal and States Government fell to $13.33 \%$ and $28.42 \%$ respectively, while that of the World Bank rose to $50 \%$. Over the period 1981 1993, the share of the Federal Government, States Government and the World Bank in the funding of the ADP system were $21.24 \%, 30.00 \%$ and $43.67 \%$ respectively. Thus, the World Bank has been the major financier of the ADP system in Nigeria. In fact, the World Bank has committed $\$ 1.2$ billion for Agricultural Development Projects (ADPs) to increase farm production and welfare among smallholders in Nigeria.(World Bank, 2001). As noted by Madukwe et al (2002), the ADP system has sought to involve Local Government Councils and Non-Governmental Organizations (NGOs) in the funding arrangement.

TABLE 1: Capital Allocations to ADPs 1981-1993

\begin{tabular}{|c|c|c|c|}
\hline Period & $\begin{array}{c}\text { Federal } \\
\text { Government (\%) }\end{array}$ & $\begin{array}{c}\text { State Government } \\
(\%)\end{array}$ & World Bank (\%) \\
\hline $1981-1985$ & 34.06 & 32.51 & 33.43 \\
\hline $1986-1993$ & 13.33 & 28.42 & 50.10 \\
\hline $1981-1993$ & 21.24 & 30.00 & 43.67 \\
\hline
\end{tabular}

Source: Adapted from Garba (2000)

Considering the fact that the number of ADPs in Nigeria increased from 7 in 1981 to 22 in 1993, it can be argued that as the number of ADPs increased, the volume of the Federal Government and States Government counterpart funds to the system decreased.

According to Agwu and Chukwuone (2005), the most difficult and challenging policy issue facing the agricultural extension services is to secure a stable source of funding. NAERLS (2008a) reports a categorization of State ADPs based on the availability of funds from their respective State Governments. Analysis of the report reveals that only 4 State ADPs: Bauchi, Kano, Kebbi and Kogi can be said to have reached the status of good funding. The bulk of the State ADPs have weak to very weak funding status. 
TABLE 2: Classification of State ADPs According to Adequacy of Funding

\begin{tabular}{|c|c|c|c|c|c|c|}
\hline State & Excellent & Very Good & Good & Fair & Weak & Very \\
\hline Abia & & & & & & 1 \\
\hline Adamawa & & & & & & 1 \\
\hline Anambra & & & & $\sqrt{ }$ & & \\
\hline Bauchi & $\sqrt{ }$ & & & & & \\
\hline Borno & & & & & & r \\
\hline FCT & & & & & & 1 \\
\hline Gombe & & & & & $\sqrt{ }$ & \\
\hline Imo & & & & & $\sqrt{ }$ & \\
\hline Jigawa & & & & & $\sqrt{ }$ & \\
\hline Kaduna & & & & $\sqrt{ }$ & & \\
\hline Kano & & $\sqrt{ }$ & & & & \\
\hline Katsina & & $\sqrt{ }$ & & & & \\
\hline Kebbi & & & $\sqrt{ }$ & & & \\
\hline Kwara & & & & & $\sqrt{ }$ & \\
\hline Kogi & & & $\sqrt{ }$ & & & \\
\hline Niger & & & & & & 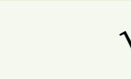 \\
\hline Ogun & & & & & $\sqrt{ }$ & \\
\hline Ondo & & & & & $\sqrt{ }$ & \\
\hline Sokoto & & & & & & 1 \\
\hline Yobe & & & & & & 1 \\
\hline Zamfara & & & & & & r \\
\hline
\end{tabular}

Source: Condensed from NAERLS (2008)

Public extension systems are facing serious funding constraints, and in many places innovative ways are being sought to fund extension services (Rivera and Alex, 2004; Ozor and Madukwe, 2005). Researchers in Nigeria have identified and advanced recommendations to tackle inadequate funding as a major problem bedeviling agricultural extension delivery system in Nigeria. Such 
recommendations include the adoption of a cost sharing approach (Agwu and Chukwuone, 2005; Chukwuone et al, 2006) and the establishment of an agricultural research and extension fund in consonance with the Petroleum Technology Development Fund (PTDF) and the Education Tax Fund (ETF) etc (Akinbale, 2008; Saliu and Age, 2009). The Cost-Sharing approach is a privatization strategy which requires the payment of a fee for agricultural services and advice, which were formerly given free of charge (Rivera and Cary, 1997).

Step 3: Identify direct causes and effects of the focal problem and construct a Problem tree showing these relationships.
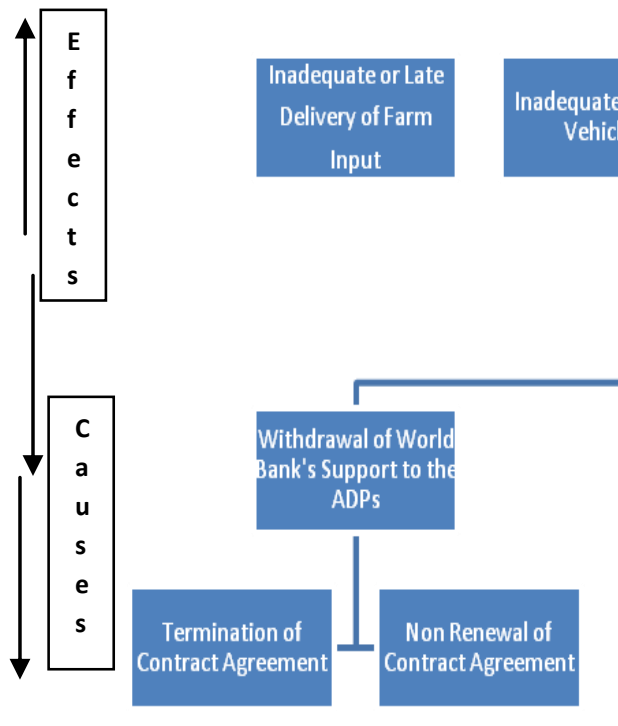

Fig.2: Developed Problem Tree 
Step 4: Transformed the Problem Tree into the Objective Tree

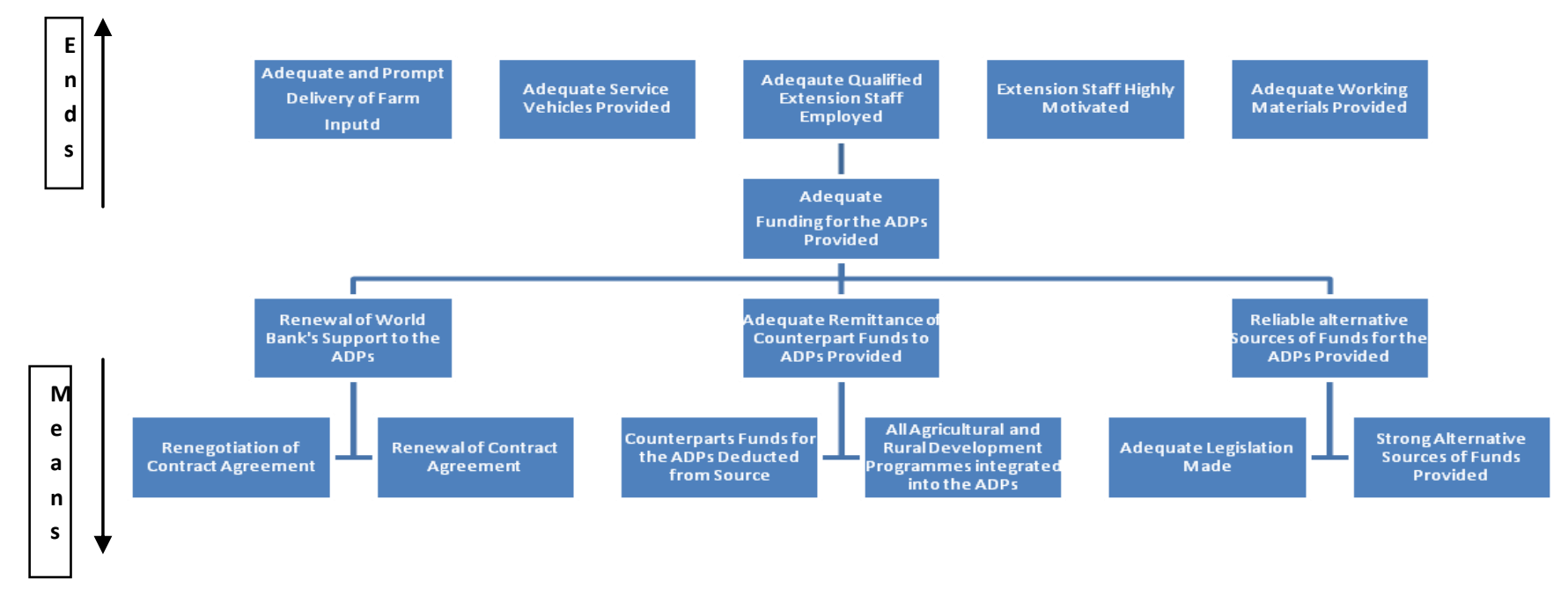

Fig. 3: Objective Tree Obtained by Converting the Developed Problem Tree

Step 5: Obtain Root Solutions to the Focal Problem from the objective tree.

Through the conversion of the Problem tree (Figure 1) to the Objective tree (Figure 2 ), the root causes of the focal problem were turned into its root solutions. The root solutions for poor funding of the ADP system in Nigeria are: (i) re-introducing World Bank's support for the ADPs (ii) Strengthening the mechanism for remitting counterpart funds to the ADPs (iii) Providing alternative and more sustainable sources of funds for the ADPs. The first root solution was discarded as it is not practicable. The remaining two were considered plausible and practicable.

\section{CONCLUSION AND RECOMMENDATIONS}

The paper employed the Problem Tree Analysis technique to conduct a situation analysis of the problems militating against the ADP system in Nigeria. The paper achieved three main objectives. First, it represented the problems identified by recent reports of the Annual Performance Survey of Agricultural Production in Nigeria and the National Agricultural Extension Review and Planning Meeting. Second, taking inadequate funding as the focal problem, it developed a problem tree and identified the root causes of the focal problem. Third, it transformed the problem tree into the objective tree and, by so doing, converted the root problems into the root solutions.

From the identified root solutions the following practical solutions are recommended: 
(a) Improving the remittance of funds to the ADPs through deductions of State and Federal Governments' counterpart funds to the ADPs from source i.e. from the federation account.

(b) Formation of an Agricultural Development Tax Fund (ADTF) fashioned not in line with the Education Tax Fund (ETF) or the Petroleum Technology Development Fund (PTDF) to provide additional and sustainable source of funds for agricultural development in Nigeria. Both the ETF and the PTDF are funded through corporate income tax. In the case of the ETF, for example, all companies registered in Nigeria are charged $2 \%$ of their annual assessable profit as education tax (FGN,1999). The proposed ADTF is to be funded through a form of indirect taxation. $2 \%$ of the total revenue generated by each of the following: the Federal Inland Revenue Service, States Board of Inland Revenue, the Nigeria Customs Service and any similar revenue generating body in Nigeria, should be diverted to fund the ADTF.

(c) All Federal and State Governments programmes/initiatives on agriculture and rural development, such as the Fadama, should be integrated into the ADP system to avoid duplication of efforts and ensure optimum and prudent use of scarce resources to make the ADPs more effective. This recommendation is in line with that of NAERLS (2008a).

\section{REFERENCES}

Agwu, A. E. and Chukwuone, N. A. (2005). Funding of Agricultural Extension in a Democratic and Deregulated Economy: The Cost-Sharing Approach. Journal of Agricultural Extension. 8 90-98.

Akinbile, L. A. (2008). Tackling the Challenges of Sustainable Agricultural Research and Extension Policy for Nigeria - a Framework. In Developing Agricultural Extension Policy for Nigeria. Proceedings of the $13^{\text {th }}$ Annual Conference of the Agricultural Extension Society of Nigeria. $8^{\text {th }}-11^{\text {th }}$ April.

Akpobo, J. G. (2007). Review of Agricultural Extension Approaches Implemented in Nigeria. In a Training Manual for Orientation/Refresher Course on Extension Communication Techniques for Extension Workers in the ADPs/LGAs in the North West Zone. Zaria: NAERLS/ABU.

AusGuideline (2005). The Logical Framework Approach. Canberra: AusAID.

Chukwuone, N. A., A. E. Agwu and Ozor N (2006). Constraints and Strategies toward Effective Cost-Sharing of Agricultural Technology Delivery in Nigeria. Journal of International Agricultural and Extension Education. 13 (1):29-41

DfID (2005). DFID's Social Development toolkit. London: DfID.

Ekpere, J. A. (1991). Agricultural Extension Searchlight of the Nigerian Small Farmer. 1990 University Lectures. Ibadan: University Press. 
FGN (1999). Education Tax (Amendment) Decree No 40 of 1998. Laws of the Federation of Nigeria. Lagos: Federal Government Press.

Garba, P. K. (2000). An analysis of the Implementation and Stability of Nigerian Agricultural Policies 1970-1993. AERC Research Paper 101. Nairobi: African Economic Research Consortium.

Guilt, I and Moiseev, A. (2001). Resource Kit for Sustainability Assessment. Cambridge:IUCN.

Holtland, G. (2005). Basic Skills in Participatory Extension Planning. Kabul: DACAAR

Madukwe, M. C, E.C. Okoli and S.O. Eze (2002) Analysis and Comparison of the Agricultural Development Programme and University Agricultural Technology Transfer Systems in Nigeria. ATPS Working Paper Series No. 35. Kenya: African Technology Policy Studies Network (ATPS)

NAERLS (2008a). Agricultural Performance Survey of 2008 Wet Season in Nigeria: National Report. Zaria: NAERLS Press.

NAERLS (2008b). National Agricultural Extension Review and Planning Meeting (2007/2008). NAERP Report No 009. Zaria: NAERLS Press.

Ozor, N and Madukwe, M. C. (2005). Strategies for Increased Private Sector Participation in Funding Agricultural Extension Services in Nigeria: The Professionals Reaction in Enugu State. Journal of Agricultural Extension. 8 7-15.

Oladele, O.I. (2004). Effects of World Bank's Loan Withdrawal on the performance of Agricultural Extension in Nigeria. Nordic Journal of African Studies 13 (2): 141-145.

Rivera, W. M. and Alex G. (2004). Extension Reform for Development Vol 1. Decentralized Systems. Agricultural and Rural Development Discussion Paper 8. Washington DC: The World Bank.

Rivera, W. M. and Cary J. H. (1997). Privatizing Agricultural Extension. In B. E. Swanson, R. P. Bentz and A. J. Sofranko (Eds) Improving Agricultural Extension: A Reference Manual. Pp 203-212.

Saliu, O. J. and A. I. Age (2009). Privatization of Agricultural Extension Services in Nigeria: Proposed Guidelines for Implementation. Journal of Sustainable Development in Africa. 11 (2): 160-176.

UNESCAP (2003). Project Planning, Monitoring and Evaluation Training Guide.

World Bank (2001). Agricultural Development Projects in Nigeria. Independent Evaluation Group (IEG). Washington DC: The World Bank. 